\title{
PENERAPAN METODE PEMBELAJARAN PROBING PROMPTING UNTUK MENINGKATKAN AKTIVITAS DAN HASIL BELAJAR SISWA PADA MATA PELAJARAN KONSTRUKSI BANGUNAN DI KELAS X PROGRAM KEAHLIAN TEKNIK GAMBAR BANGUNAN SMK NEGERI 1 STABAT
}

\author{
Lukmannul Hakim Siregar ${ }^{1}$, Rachmat Mulyana ${ }^{2}$ \\ ${ }^{1}$ Alumni Program Studi Pendidikan Teknik Bangunan, Fakultas Teknik UNIMED \\ ${ }^{2}$ Dosen Pengajar Jurusan Pendidikan Teknik Bangunan, Fakultas Teknik UNIMED \\ (rachmatmulyana@gmail.com)
}

\begin{abstract}
ABSTRAK
Penelitian ini merupakan Penelitian Tindakan Kelas (PTK) yang bertujuan untuk mengetahui peningkatkan aktivitas dan hasil belajar Konstrusi Bangunan pada kelas $\mathrm{X}$ program keahlian teknik gambar bangunan terhadap penerapan metode pembelajaran Probing Prompting. Penelitian ini dilakukan pada semester ganjil tahun pelajaran 2015/2016 dengan jumlah siswa 30 orang. Teknik pengumpulan data dengan observasi dan tes hasil belajar. Berdasarkan hasil penelitian dapat diketahui bahwa metode pembelajaran Probing Prompting dapat meningkatkan aktifitas dan hasil belajar siswa. Peningkatan ini dapat dilihat pada dua siklus pembelajaran yang berlangsung di kelas. Berdasarkan hasil evaluasi proses, hasil pada setiap pembelajaran, dan berdasarkan kriteria keberhasilan yang telah ditetapkan dalam penelitian ini, ditemukan siklus I nilai rata-rata aktivitas belajar siswa yaitu 69,40 meningkat menjadi 81,33 pada siklus II. Untuk nilai hasil belajar pada siklus I yaitu 72,21 dan meningkat sebesar $13 \%$ menjadi 85 pada siklus II. Dapat disimpulkan bahwa dengan metode pembelajaran Probing Prompting dapat dapat meningkatkan aktivitas belajar dan hasil belajar Konstruksi Bangunanpada siswa kelas X Program Keahlian Teknik Gambar Bangunan SMK Negeri 1 Stabat Tahun Ajaran 2015/ 2016.
\end{abstract}

Kata Kunci : Aktivitas, Hasil Belajar, Probing Prompting,

\begin{abstract}
This research is a classroom action research (CAR), which aims to determine the activity and enhancing learning outcomes Building on the class X program engineering drawings of buildings on the application of learning methods Probing Prompting. This research was conducted in the first semester of the school year 2015/2016 the number of students 30 people. The technique of collecting data through observation and tests of learning outcomes. Based on the results of this research is that learning methods Probing Prompting can improve learning outcomes siswa.Peningkatan activity and this can be seen in two cycles of learning that takes place in the classroom. Based on the evaluation process, the results in each study, and based on the success criteria set out in this study, it was found the first cycle of the average value of student activity that is 69.40 increased to 81.33 in the second cycle. For the value of learning outcomes in the first cycle is 72.21 and increased by $13 \%$ to 85 in the second cycle. It can be concluded that the learning method can Probing Prompting can increase the activity of learning and learning outcomes Building Construction in class X Architecture Engineering Expertise Program SMK 1 Stabat Academic Year 2015/2016.
\end{abstract}




\section{Pendahuluan}

Salah satu indikator untuk mengukur tingkat keberhasilan dalam proses belajar mengajar dikelas adalah hasil belajar siswa. Hasil belajar siswa ini diukur selama proses pembelajaran berlangsung. Ujian semester, tugas dan juga tingkat kehadiran merupakan beberapa cara untuk menentukan nilai dari hasil belajar. Rendahnya hasil belajar dapat dilihat dari nilai rata-rata dengan nilai yang telah disepakati oleh guru dan pihak sekolah melalui rapat dewan guru. Berdasarkan pengamatan dan observasi langsung yang dilakukan oleh peneliti terlihat bahwa perolehan nilai untuk mata pelajaran Konstruksi Bangunan masih rendah. Hal ini terlihat dari evaluasi perolehan rata-rata nilai mata pelajaran Konstruksi Bangunan pada Tahun Ajaran 2014/2015 yang lalu untuk kelas $X$ yang memperoleh nilai rata-rata 75,00.

Berdasarkan observasi awal yang peneliti lakukan di SMK Negeri 1 Stabat pada siswa kelas X Program Keahlian Teknik Gambar Bangunan, peneliti melakukan wawancara kepada guru mata pelajaran dan meminta dokumen-dokumen seperti nilai, absensi siswa, melihat kondisi kelas saat proses pembelajaran, dan bertanya kepada siswa tentang metode mengajar guru yang dirasakan siswa. bahwa dari observasi tersebut didapatkan, hasil belajar pada mata pelajaran Konstruksi Bangunan untuk tahun ajaran 2014/2015 belum sesuai dengan harapan yang ada pada Nilai Ulangan Harian SMK Negeri 1 Stabat. Untuk lebih jelas dapat dilihat pada tabel berikut :

\begin{tabular}{|c|c|c|c|c|c|c|c|c|c|}
\hline \multirow{4}{*}{$\begin{array}{l}\text { Tahun } \\
\text { Pelajaran }\end{array}$} & \multirow{4}{*}{ Nilai } & \multirow{4}{*}{ Predikat } & \multicolumn{2}{|c|}{ UHI } & \multicolumn{2}{|c|}{$\mathrm{UH} 2$} & \multicolumn{2}{|c|}{ UHB } & \multirow{4}{*}{$\begin{array}{l}\text { Jumlah } \\
\text { Siswa }\end{array}$} \\
\hline & & & \multirow{3}{*}{ Sistra } & Persentas & \multirow{3}{*}{ Siswa } & Persentas & & Persentas & \\
\hline & & & & e & & e & & e & \\
\hline & & & & $\%$ & & $\%$ & Siswa & $\%$ & \\
\hline \multirow{4}{*}{20142015} & $\checkmark 74$ & Tidak Tunta & 11 & 36.67 & 12 & 40 & 14 & 46.67 & 37 \\
\hline & $75-79$ & Cukup & 15 & 50 & 10 & 33.33 & 10 & 33.33 & 35 \\
\hline & $80-89$ & Baik & 4 & 13.33 & 6 & 20 & 6 & 20 & 16 \\
\hline & $90-100$ & Sangat Baik & - & - & 2 & 6.67 & - & - & 2 \\
\hline \multicolumn{3}{|c|}{ Jumlah } & 30 & 100 & 30 & 100 & 30 & 100 & 90 \\
\hline
\end{tabular}

Tabel 1 Nilai Ulangan Harian SMK Negeri 1 Stabat
Dari tabel Nilai ulangan harian diatas, diatas dapat dilihat perbedaan yang sangat mencolok antara yang nilai siswa yang lulus KKM (Kreteria Ketuntasan Minimal) dengan nilai siswa yang tidak lulus. Berdasarkan Kriteria Ketuntasan Minimum (KKM) yang ditetapkan sekolah adalah 75, maka dilihat pada nilai ulangan harian pertama terdapat 36,67\% tidak tuntas dan $63,33 \%$ tuntas, pada ulangan harian kedua terdapat $40,00 \%$ tidak tuntas dan $60,00 \%$ tuntas, pada ulangan harian ketiga terdapat $46,67 \%$ tidak tuntas dan 53,33\% tuntas. Dengan demikian kelas tersebut belum tuntas belajar.

Berhasil atau tidaknya suatu pendidikan sangat dipengaruhi oleh pembelajaran yang berlangsung. Pembelajaran adalah suatu proses yang rumit karena tidak sekedar menyerap informasi dari guru tetapi melibatkan berbagai kegiatan dan tindakan yang harus dilakukan untuk mendapatkan hasil belajar yang lebih baik. Rendahnya hasil belajar Konstruksi Bangunan pada siswa kelas X Teknik Gambar Bangunan SMK Negeri 1Stabat, terjadi karena penggunaan metode pembelajaran yang digunakan oleh guru kurang efektif. Selain hasil belajar yang masih rendah, keaktifan siswa dalam proses pembelajaran juga masih rendah. Hal ini disebabkan karena pembelajaran masih monoton, sehingga aktivitas belajar siswa kurang aktif.

Informasi lain yang peneliti peroleh dari observasi melihat keadaan kelas saat proses belajar mengajar adalah aktivitas belajar siswa dalam kegiatan pembelajaran rendah, terlihat sedikit siswa yang merespon pembelajaran, sebagian dari siswa kurang aktif. Hal ini dikarenakan, aktivitas belajar siswa dalam pembelajaran Konstruksi Bangunanseperti bertanya atau mengemukakan pendapat atau bahkan beradu argumen masih jarang terjadi. Dalam hal ini siswa cenderung hanya menerima pelajaran, kurang memiliki keberanian dalam menyampaikan pendapat, tidak bertanya bila ada materi yang kurang jelas, kurang memiliki kemampuan merumuskan gagasan sendiri dan siswa belum terbiasa bersaing dalam menyampaikan pendapat kepada orang lain. Hal ini menunjukkan aktivitas belajar siswa masih rendah, sehingga perlu inovasi baru dalam 


\section{Penerapan Metode Pembelajaran Probing Prompting Untuk Meningkatkan Aktivitas dan Hasil Belajar Siswa Pada Mata Pelajaran Konstruksi Bangunan di Kelas X Program Keahlian Tenik Gambar Bangunan SMK Negeri 1 Stabat}

proses belajar mengajar agar aktivitas belajar dikelas menjadi tinggi.

Metode pembelajaran yang kurang tepat dan kurang bervariasi merupakan salah satu faktor yang mempengaruhi aktivitas dan hasil belajar. Salah satu cara yang dapat digunakan guru adalah tidak menggunakan satu metode saja yang akan membuat siswa tidak tertarik dalam proses belajar mengajar yang mengakibatkan rendahnya aktivitas dan hasil belajar siswa, Hal senada juga diungkapkan oleh Slameto (2010:54) yaitu : Tidak tercapainya hasil belajar siswa seperti yang diharapkan dipengaruhi oleh berbagai macam faktor. Faktor tersebut dapat digolongkan atas dua golongan besar yaitu (1) faktor yang berasal dari dalam diri siswa (internal) yang meliputi faktor fisiologi, (2) faktor yang berasal dari luar diri siswa (eksternal) yang meliputi faktor lingkungan dan faktor instrumental.

Penggunaan metode pembelajaran merupakan suatu faktor yang mempengaruhi aktivitas dan hasil belajar siswa. Dalam hal ini peran guru sangat penting dalam proses belajar mengajar. Salah satu tugas guru dapat diartikan sebagai kegiatan yang ditujukan untuk membelajarkan siswa, dimana siswa berpartisipasi aktif dalam proses pembelajaran dan memotivasi siswa. Namun kenyataannya guru masih menerapkan metode pembelajaran konvensional. Proses pembelajaran hanya terfokus pada kebiasaan guru dalam mengajar pada umumnya, seperti menjelaskan materi yang monoton dan konvensional. Namun demikian, konvensional bukan berarti salah. Akan tetapi, untuk siswa kelas X SMK Negeri 1Stabat metode tersebut membawa kejenuhan. Pengelolaan suasana belajar yang kurang dan siswa tidak diajak untuk berpikir bersama tentang materi yang sedang diajarkan. Oleh karena itu, bahwa kurang tepatnya guru mengajar dengan menggunakan metode pembelajaran di atas menjadi penyebab siswa kurang aktif.

Diperlukan adanya suatu inovasi terhadap kegiatan pembelajaran yang berlangsung dikelas, sebagai alternatif pemecahan masalah dikelas peneliti merencanakan untuk melakukan penelitian tindakan kelas menggunakan metode pembelajaran Probing Promting.Upaya yang peneliti lakukan untuk membantu meningkatkan aktivitas dan hasil belajar siswa adalah menggunakan metode yang sedikit berbeda dengan metode yang dilakukan para guru SMK Negeri 1 Stabat biasanya. Metode ini merupakan metode baru di lingkungan SMK Negeri 1Stabat.

Menurut Ngalimun, (2013:165) pembelajaran Probing Prompting adalah pembelajaran dengan cara guru menyajikan serangkaian pertanyaan yang sifatnya menuntun dan menggali gagasan siswa sehingga terjadi proses berpikir yang mampu mengaitkan pengetahuan dan pengalaman siswa dengan pengetahuan baru yang sedang dipelajari. Selanjutnya, siswa mengkonstruksi konsep, prinsip, dan aturan menjadi pengetahuan baru.

Kurang aktif dan rendahnya hasil belajar siswa dipengaruhi oleh kurang terlibatnya siswa dalam kegiatan pembelajaran, karena metode pembelajaran yang diterapkan dikelas masih relatif kurang tepat sehingga membuat siswa tidak bersemangat mengikuti pembelajaran di kelas. Oleh karena itu, salah satu langkah yang harus ditempuh guru adalah dengan menggunakan metode pembelajaran yang dapat meningkatkan hasil belajar siswa. Salah satunya adalah metode pembelajaran Probing Prompting. Menurut arti katanya, Probing adalah penyelidikan, pemeriksaan, sedangkan menurut istilahProbing berarti berusaha memperoleh keterangan yang lebih jelas atau mendalam. Prompting dalam bahasa berarti mengarahkan, mendorong atau menuntun. Sedangkan Prompting menurut istilah adalah pertanyaan yang diajukan untuk memberikan arah kepada siswa dalam proses berfikirnya. Didalam metode pembelajaran ini guru menyajikan serangkaian pertanyaan yang sifatnya menuntun dan menggali sehingga terjadi proses berfikir yang mengkaitkan pengetahuan siswa dan pengalaman siswa dengan pengetahuan baru yang sedang dipelajari.

Oleh karena itu, Penerapan Metode Pembelajaran Probing Prompting diharapkan dapat meningkatkan aktivitas dan hasil belajar. Rumusan masalah penelitian ini adalah:

a. Apakah dengan penerapan Metode Pembelajaran Probing Prompting dapat meningkatkan aktivitas belajar siswa pada mata pelajaran Konstruksi Bangunankompetensi jenis dan fungsi struktur bangunan kelas $X$ Program Keahlian Teknik Gambar Bangunan SMK Negeri 1 Stabat tahun pelajaran 2015/2016 ?

b. Apakah penerapan Metode Pembelajaran Probing Prompting dapat meningkatkan hasil belajar siswa pada mata pelajaran Konstruksi Bangunankompetensi jenis dan 
fungsi struktur bangunan kelas $X$ Program Keahlian Teknik Gambar Bangunan SMK Negeri 1 Stabat tahun pelajaran 2015/2016?

Sejalan dengan rumusan masalah di atas, maka tujuan penelitian tindakan kelas ini adalah:

a. Untuk mengetahui peningkatan aktivitas belajar siswakelas $\mathrm{X}$ pada mata pelajaran konstruksi bangunan kompetensi jenis dan fungsi struktur bangunan kelas $X$ Program Keahlian Teknik Gambar Bangunan SMK Negeri 1 Stabat tahun pelajaran 2015/2016 dengan menerapkan metode pembelajaran Probing Prompting.

b. Untuk mengetahui peningkatanHasil Belajar siswa kelas $X$ pada mata pelajaran konstruksi bangunan kompetensi jenis dan fungsi struktur bangunan kelas $X$ Program Keahlian Teknik Gambar Bangunan SMK Negeri 1 Stabat tahun pelajaran 2015/2016 dengan menerapkan metode pembelajaran Probing Prompting.

\section{Kajian Teori}

\section{Menurut}

Ngalimun

(2012:165)

"Pembelajaran Probing Prompting adalah pembelajaran dengan menyajikan serangkaian pertanyaan yang sifatnya menuntun dan menggali gagasan siswa sehingga terjadi proses berpikir yang mampu mengaitkan pengetahuan dan pengalaman siswa dengan pengetahuan baru yang sedang dipelajari. Selanjutnya, siswa mengkonstruksi konsep, prinsip, dan aturan menjadi pengetahuan baru, dan dengan demikian pengetahuan baru tidak diberitahukan". Sedangkan Menurut Suherman (dalam Huda, Miftahul,2013:281) menyatakan bahwa, "Probing adalah menggali atau melacak, dan Prompting adalah mengarahkan atau menuntun". Secara umum pembelajaran dengan menggunakan Probing Promptingadalah pembelajaran dengan cara guru menyajikan serangkaian pertanyaan yang sifatnya menuntun dan menggali sehingga terjadi proses berpikir yang mengaitkan pengetahuan baru yang sedang dipelajari.

Langkah-langkah pembelajaran Probing Prompting dijabarkan melalui tujuh tahapan oleh Sudarti (dalam Huda, Miftahul, 2014:282) metode Probing yang dikembangkan dengan Prompting adalah sebagai berikut:

a. Guru menghadapkan siswa pada situasi baru, misalkan dengan memperhatikan gambar, rumus, atau situasi lainnya yang mengandung permasalahan.

b. Menunggu beberapa saat untuk memberikan kesempatan kepada siswa untuk merumuskan jawaban atau melakukan diskusi kecil dalam merumuskannya.

c. Guru mengajukan persoaalan kepada siswa yang sesuai dengan Tujuan Pembelajaran Khusus (TPK) atau indikator kepada seluruh siswa.

d. Menunggu beberapa saat untuk memberikan kesempatan kepada siswa untuk merumuskan jawaban atau melakukan diskusi kecil dalam merumuskannya.

e. Menunjuk salah satu siswa untuk menjawab pertanyaan.

f. Jika jawabannya tepat maka guru meminta tanggapan kepada siswa lain dalam kegiatan tersebut untuk menyakinkan bahwa seluruh siswa terlibat dalam kegiatan yang sedang berlangsung. Namun jika siswa tersebut mengalami kesulitan dalam menjawab, seperti jawaban yang diberikan kurang tepat, tidak tepat, atau diam, maka guru mengajukan pertanyaan-pertanyaan lain yang jawabannya merupakan petunjuk jalan penyelesaian jawaban. Lalu dilanjutkan dengan pertanyaan yang menuntun siswa berpikir pada tingkat yang lebih tinggi, sampai dapat menjawab pertanyaan sesuai dengan kompetensi dasar atau indikator. Pertanyaan yang dilakukan pada langkah keenam ini sebaiknya diajukan pada beberapa siswa yang berbeda agar seluruh siswa terlibat dalam seluruh kegiatan Probing Prompting.

g. Guru mengajukan pertanyaan akhir pada siswa yang berbeda untuk lebih menekankan bahwa Tujuan Pembelajaran Khusus (TPK)/ indikator tersebut benarbenar telah dipahami seluruh siswa.

Menurut Sardiman (2009:95) mengatakan bahwa "pada perinsipnya prinsip belajar adalah berbuat untuk merubah tingkah laku". Maka, tidak ada belajar tanpa disertai aktivitas.Itu sebabnya aktivitas merupakan prinsip yang penting didalam interaksi pembelajaran. Sedangkan Djamarah (2008:38) mengatakan bahwa"belajar bukanlah proses dalam kehampaan, tidak pula sepi dari berbagai aktivitas. Tidak pernah terlihat orang ayang belajar tanpa melibatkan aktivitas raganya". 


\section{Penerapan Metode Pembelajaran Probing Prompting Untuk Meningkatkan Aktivitas dan Hasil Belajar Siswa Pada Mata Pelajaran Konstruksi Bangunan di Kelas X Program Keahlian Tenik Gambar Bangunan SMK Negeri 1 Stabat}

Menurut Sanjaya (2006:132) bahwa "aktivitas tidak dimaksudkan terbatas pada aktivitas fisik, tetapi juga meliputi aktivitas yang bersifat psikis seperti aktivitas mental". Sedangkan Rohani (2004:6) berpendapat bahwa"seorang anak berpikir sepanjang ia berbuat. Tanpa berbuat anak tak dapat berpikir.Agar ia berpikir sendiri, ia harus diberikan kesempatan untuk berbuat sendiri". Dua aktivitas (fisik dan psikis) ini harus dipandang sebagai hubungan yang erat, maka pada saat siswa aktif jasmaninya, dengan sendirinya juga aktif jiwanya. Namun, siswa dikatakan aktif (on task), apabila tidak melakukan penyimpangan dalam hal berbicara di luar pelajaran, memandang ke kiri ke kanan, mengganggu teman, mencari perhatian, mengerjakan tugas lain, keluar masuk kelas.

Dengan demikian dapat di simpulkan aktivitas itu harus diperoleh dengan pengamatan sendiri, pengalaman sendiri, penyelidikan sendiri, dengan bekerja sendiri, dengan fasilitas yang diciptakan sendiri baik secara rohani maupun teknis. Ini menunjukkan setiap orang yang belajar harus aktif sendiri, tidak ada belajar kalau tidak ada aktivitas.

Menurut Sudjana (dalam Kunandar, 2008:276)

"hasil belajar adalah suatu akibat dari proses belajar dengan menggunakan alat pengukuran, yang berupa tes yang disusun secara terencana, baik tes tertulis, tes lisan, maupun tes perbuatan". Sedangkan S. Nasution (dalam Kunandar, 2008: 35) juga menyatakan bahwa "hasil belajar adalah suatu perubahan pada individu yang belajar, tidak hanya mengenai pengetahuan tetapi juga membentuk kecakapan dan penghayatan dalam diri pribadi individu yang belajar".

Menurut Bloom (dalam Sardiman, 2009:23),ada tiga kemampuan yang diharapkan siswa sebagai hasil belajar antara lain yaitu :

a. Kognitif Domain

b. Affective Domain

c. Psycomotor Domain

Berdasarkan pendapat diatas, maka dapat disimpulkan bahwa hasil belajar adalah hasil akhir yang diperoleh dari proses belajar mengajar. Hasil yang diperoleh merupakan suatu perubahan tingkah laku menuju kepada yang lebih baik dari sebelumnya, dan dapat diketahui setelah seorang siswa telah mendapat pelajaran disekolah.

Pada penilaian tindakan kelas ini, yang di maksud hasil belajar siswa adalah hasil belajar siswa pada mata pelajaran Konstruksi
Bangunan. Hasil belajar dapat berupa tes hasil belajar yang dilakukan setiap selesai proses pembelajaran dalam satuan bahasan atau kompetensi tertentu. Tes hasil belajar ini terdiri dari seperangkat soal yang harus dijawab oleh peserta didik dan tugas-tugas terstruktur yang berkaitan dengan konsep yang sedang dibahas. Dengan demikian hasil belajar merupakan kemampuan dan perubahan tingkah laku yang dimiliki seseorang setelah proses pembelajaran. Proses pembelajaran bersifat kompleks karena di dalamnya kegiatan guru dan kegiatan belajar dari pihak siswa saling berinteraksi, siswa masuk sekolah untuk belajar sedang guru mendampingi dan menuntun siswa dalam mempelajari materi pembelajaran.

Dalam penelitian ini, hasil belajar yang ingin di teliti adalah hasil belajar mata pelajaran Konstruksi Bangunan.Konstruksi Bangunan adalah salah satu ilmu yang mempelajari dasardasar pengenalan bangunan gedung. Materi yang mencakup adalah bagian-bagian dari konstruksi bangunan bawah dan atas, pelaksanaan pemasangan pondasi dan pekerjaan dinding. Dengan demikian hasil belajar Konstruksi Bangunan adalah pencapaian proses belajar mengajar terhadap mata pelajaran Konstruksi Bangunan yang diukur dengan tes hasil belajar.

\section{Metodologi Penelitian}

Pelaksanaan penelitian ini dilaksanakan pada semester ganjil tahun pelajaran 2015/2016, yaitu tanggal 12 Oktober 2015 sampai dengan 10 November 2015.Penelitian tindakan kelas ini dilaksanakan di SMK Negeri I Stabat Program Keahlian Teknik Gambar Bangunan beralamat di Jalan K. H Wahid Hasyim Stabat Kabupaten Langkat.

Subjek dalam penelitian ini adalah kelas $X$ Program Keahlian Teknik Gambar Bangunan Tahun Ajaran 2014/2015 dengan jumlah siswa sebanyak 30 orang siswa yang terdiri dari 17 orang siswa laki-laki dan 13 orang siswa perempuan. Dan yang menjadi obyek dalam penelitian ini adalah penerapan metode Probing Promting untuk meningkatkan aktivitas dan hasil belajar konstruksi bangunan kelas $X$ program keahlian teknik gambar bangunan SMK Negeri 1 Stabat.

Definisi operasional dalam penelitian ini adalah :

a. Metode pembelajaran Probing Prompting,

b. Aktivitas belajar, 
c. Hasil belajar,

d. Penelitian Tindakan Kelas,

Penelitian ini merupakan jenis Penelitian Tindakan Kelas (Classroom Action Research).Penelitian Tindakan Kelas yaitu penelitian yang dilakukan oleh guru, bekerja sama dengan peneliti. Penelitian tindakan kelas ini dilaksanakan melalui dua siklus dan masing-masing siklus terdiri dari empat tindakan yaitu (1) Perencanaan Tindakan, (2) Pelaksanaan Tindakan, (3) Pengamatan, dan (4) Refleksi.Keempat tindakan ini bertujuan untuk melihat peningkatan hasil belajar melalui penerapan metode pembelajaran Probing Prompting.Penelitian tindakan kelas memiliki beberapa metode yang dapat digunakan, namun dalam penelitian ini menggunakan metode yang dipakai oleh Arikunto (2006:35).

Metode pemecahan masalah yang akan digunakan yaitu Penelitian Tindakan Kelas (PTK) dengan menerapkan metode Probing Prompting. Harapan yang diinginkan dengan metode pembelajaran ini adalah aktivitas dan hasil belajar siswa pada pelajaran Konstruksi Bangunan pada materi Ruang lingkup pembangunan bagian-bagian konstruksi bangunan. Tindakan tersebut diberikan oleh guru atau dengan arahan dari guru yang dilakukan oleh siswa. Untuk memperbaiki permasalahan yang ada, peneliti menggunakan metode Probing Prompting. Diharapkan dengan Probing Prompting dapat meningkatkan hasil belajar mata pelajaran Konstruksi Bangunan pada kelas X Program Keahlian Teknik Gambar Bangunan.

Penelitian tindakan kelas ini dilakukan selama pembelajaran Konstruksi Bangunan berlangsung, materi yang diteliti adalah Ruang lingkup pembangunan bagian-bagian konstruksi bangunan dan pelaksanaan pekerjaan pondasi dan dinding bata. Sebelum penelitian tindakan kelas ini dilakukan, terlebih dahulu dilakukan persiapan-persiapan sebagai berikut:

Adapun langkah-langkah yang dilakukan dalam proses penelitian tindakan ini adalah :

a. Melakukan observasi lingkungan sekolah, guru yang sedang mengajar dan siswa yang menjadi objek penelitian.

b. Melakukan diskusi dengan PKS I dan tentang kerjasama dengan guru mata pelajaran Konstruksi Bangunan untuk penerapan metode pembelajaran ProbingPrompting dalam pembelajaran. c. Melakukan proses pembelajaran dengan menggunakan metode pembelajaran ProbingPrompting, dimana aktivitas belajar siswa diamati pada saat siswa bertanya dan diberikan pertanyaan, dengan menjelaskan terlebih dahulu cara kerja metode pembelajaran ProbingPrompting kepada siswa.

d. Setelah proses pembelajaran dengan metode pembelajaran ProbingPrompting selesai maka siswa diberikan tes dengan tujuan untuk mengetahui apakah hasil belajar siswa mengalami peningkatan.

e. Melakukan refleksi dengan melihat hasil observasi aktivitas siswa dan hasil tes belajar siswa yang dijadikan sebagai dasar untuk melakukan siklus berikutnya.

Prosedur penelitian merupakan tahapantahapan atau kegiatan yang dilakukan dalam proses penelitian. Pelaksanaan tindakan ini dilaksanakan dalam dua siklus, adapun pelaksanaan tindakan yang dilakukan selama dua siklus.

Tes menggunakan bentuk pilihan berganda yang terdiri dari 4 pilihan. Setiap pilihan mempunyai 1 jawaban yang benar dan 3 pengecoh. Setiap butir yang dijawab benar diberi nilai 1 dan yang di jawab salah diberi nilai 0. Adapun jumlah soal pilihan berganda sebanyak 50 soal. Pada siklus I sebanyak 25 soal, dan pada siklus II 25 soal yang digunakan untuk memperoleh data hasil belajar Tes dilaksanakan untuk melihat hasil belajar siswa setelah pelaksanaan tindakan pada kompetesi yang ditetapkan.

Setelah dilaksanakan Uji Instrumen Tes untuk melihat hasil validitas tes didapatkan 10 (sepuluh) butir soal yang tidak valid dan 40 butir soal dinyatkan valid. Secara lebih detail distribusi intrumen tes dapat dilihat dalam kisi-kisi instrumen. Observasi dipergunakan untuk mengumpulkan data tentang aktivitas dan kemampuan belajar siswa dalam proses belajar mengajar dengan penerapan metode pembelajaran Probing Prompting. Adapun format lembar observasi aktivitas belajar siswa yang disusun oleh tim PLPG.

Uji coba instrumen pada penelitian ini direncanakan pada siswa kelas XI Program Keahlian Teknik Gambar Bangunan SMK Negeri 1 Stabat. Uji coba instrumen penelitian ini dilakukan untuk mendapatkan alat ukur yang benar-benar dapat melingkupi data yang akurat agar kesimpulan yang diambil sesuai dengan kenyataan. Adapun yang diuji dalam 


\section{Penerapan Metode Pembelajaran Probing Prompting Untuk Meningkatkan Aktivitas dan Hasil Belajar Siswa Pada Mata Pelajaran Konstruksi Bangunan di Kelas X Program Keahlian Tenik Gambar Bangunan SMK Negeri 1 Stabat}

uji coba instrumen penelitian ini adalah instrumen penelitian berupa soal (tes) agar diperoleh instrumen yang valid dan reliabel. Untuk mengetahui apakah butir soal yang dibuat mempunyai indeks kesukaran dan daya pembeda yang baik.

Untuk mengetahui gambaran tentang pengetahuan awal dan hasil belajar akhir, diperoleh dari data pretes dan postes.Tes yang berbentuk pilihan berganda yang mana terdiri dari empat pilihan dimana jawaban yang benar diberi skor 1 (satu) dan untuk jawaban yang salah diberi skor 0 (nol).

Selanjutnya untuk aktifitas dan hasil belajar dilakukan dengan menganalisis nilai rata-rata tes.Kategori penilaian tes dilakukan berdasarkan standar penilaian yang dilakukan sekolah sebagai berikut.

Kriteria penilaian skor hasil belajar

perentaseskor $=\frac{\text { skoryangdiperolehsiswa }}{\text { jumlahskor }} \times 100 \%$

Hasil kriteria penilaian skor dikategorikan sebagai berikut :

$\begin{array}{ll}90 \%-100 \% & \text { (Sangat Baik) } \\ 80 \%-89 \% & \text { (Baik) } \\ 75 \%-79 \% & \text { (Cukup) } \\ <74 \% & \text { (Kurang Baik) }\end{array}$

\section{Hasil dan Pembahasan}

Pertemuan ini dilaksanakan pada hari rabu28 Oktober 2015 dan sabtu 31 Oktober 2015 pada pukul 10.30 sampai pukul 12.30 WIB.Pada pertemuan ini pemberian tindakan dengan melakukan kegiatan belajar mengajar sesuai dengan rencana yang telah disusun dimana guru bidang studi bertindak didalam kelas sebagai pengajar. Pembelajaran dilakukan dengan menerapkan motode pembelajaran Probing Prompting, terlebih dahulu dilakukan pretest pada siswa kelas X Program Keahlian Teknik Gambar Bangunan SMK Negeri 1 Stabat. Pretest ini terdiri dari 20 soal yang telah diuji cobakan terlebih dahulu pada siswa kelas XI Program Keahlian Teknik Gambar Bangunan SMK Negeri 1 Stabat. Setelah pretest dilakukan maka proses pembelajaran dilakukan dengan menerapkan metode pembelajaran Probing Prompting pada mata pelajaran konstruksi bangunan. Dan pada akhir siklus pertama siswa kembali diuji dengan postes untuk mengetahui peningkatan hasil belajar siswa. Setelah selesai maka peneliti melakukan analisa data yang diperoleh pada siklus I dan merekap semua data siklus pertama.Dapat dilihat pada grafik berikut ini :

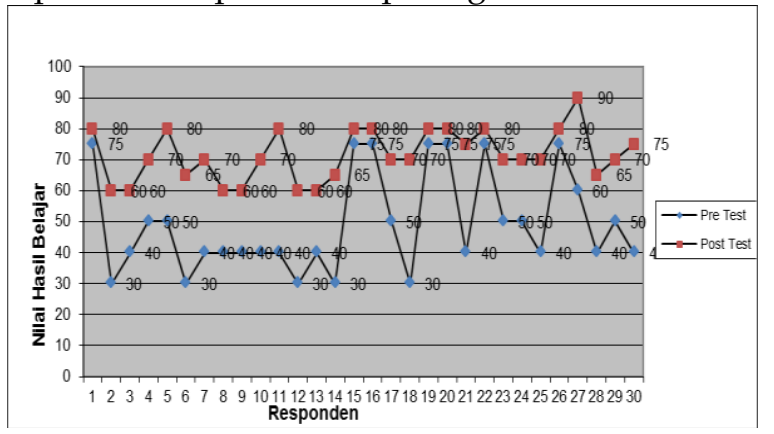

Gambar 1 Grafik hasil Belajar siswa Pada Siklus 1

Dari hasil pretest dan postest yang disajikan pada gambar 1 diatas, diketahui bahwa hasil pretest dengan kategori cukup 6 siswa (23\%), yang tuntas sesuai dengan standart KKM (75) selebihnya sebanyak 24 siswa (77\%) dinyatakan tidak tuntas. Nilai rata-rata pretestyang dilakukan diperoleh hasil dengan rata-rata 49,33\% yaitu tidak tuntas.

Setelah dilakukan pembelajaran selama dua pertemuan dengan penerapan metode pembelajaran Probing Prompting hasilnya pembelajaran meningkat, ini ditandai dengan peningkatan hasil postest yaitu dengan kategori cukup 11 siswa $(36,66 \%)$, baik 9 siswa (30\%), selebihnya sebanyak 10 siswa $(33,33 \%)$ dinyatakan tidak tuntas. Nilai rata-rata untuk postest meningkat menjadi $72,33 \%$, sedangkan presentase kelulusan sebesar 67,33 \%. Tetapi prosentase kelulusan ini masih dibawah dari nilai indikator keberhasilan siswa yaitu $75 \%$.

Dari data hasil observasi terhadap aktivitas siswa, dapat disimpulkan bahwa aktivitas siswa selama mengikuti proses pembelajaran dengan menggunakan metode pembelajaranProbing Prompting dinyatakan tidak aktif yaitu hanya mencapai rata-rata $69,40 \%$.

Siklus kedua ini dilaksanakan dalam dua kali pertemuan. Pertemuan ini dilaksanakan pada hari rabu 04November 2015 dan sabtu 07 November 2015 pada pukul 10.30 sampai pukul 12.30 WIB.Pada pertemuan ini pemberian tindakan dengan melakukan kegiatan belajar mengajar sesuai dengan rencana yang telah disusun dimana guru bidang studi bertindak didalam kelas sebagai pengajar. Pembelajaran dilakukan dengan menerapkan motode pembelajaran 
ProbingPrompting, terlebih dahulu dilakukan pretest pada siswa kelas X Program Keahlian Teknik Gambar Bangunan SMK Negeri 1 Stabat. Pretest ini terdiri dari 20 soal yang telah diujicobakan terlebih dahulu pada siswa kelas XI Program keahlian Teknik Gambar Bangunan SMK Negeri 1 Stabat. Setelah pretest dilakukan maka proses pembelajaran dilakukan dengan menerapkan metode pembelajaran Probing Prompting pada mata pelajaran konstruksi bangunan. Dan pada akhir siklus kedua siswa kembali diuji dengan postes untuk mengetahui peningkatan hasil belajar siswa. Setelah selesai maka peneliti melakukan analisa data yang diperoleh pada siklus II dan merekap semua data siklus кеuud.vapaı ummı pada grafik berikut ini:

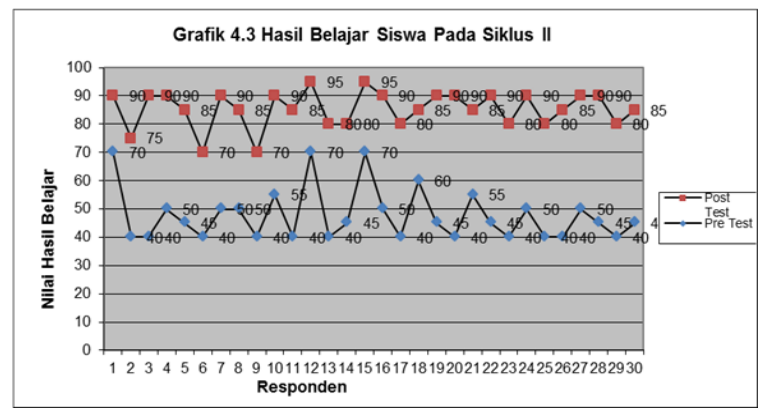

\section{Gambar 2 Grafik Hasil Belajar siswa Pada Siklus I}

Dari hasil pretest dan postest yang disajikan pada gambar 2 diatas, diketahui bahwa hasil pretest hanya 13 siswa $(43,33 \%)$ yang tuntas sesuai dengan standart KKM (75) selebihnya sebanyak 17 siswa $(56,64 \%)$ dinyatakan tidak tuntas. Nilai rata-rata pretestyang dilakukan diperoleh hasil dengan rata-rata 67.

Setelah dilakukan pembelajaran selama dua pertemuan dengan penerapan metode pembelajaran Probing Prompting hasilnya pembelajaran meningkat, ini ditandai dengan peningkatan hasil postest yaitu sebanyak 28 siswa $(93,43 \%)$ tuntas dan 2 siswa $(6,67 \%)$ dinyatakan tidak tuntas. Nilai rata-rata untuk postest meningkat menjadi $85 \%$, sedangkan prosentase kelulusan sebesar 93,43\%.Dapat dilihat pada gambar berikut ini :

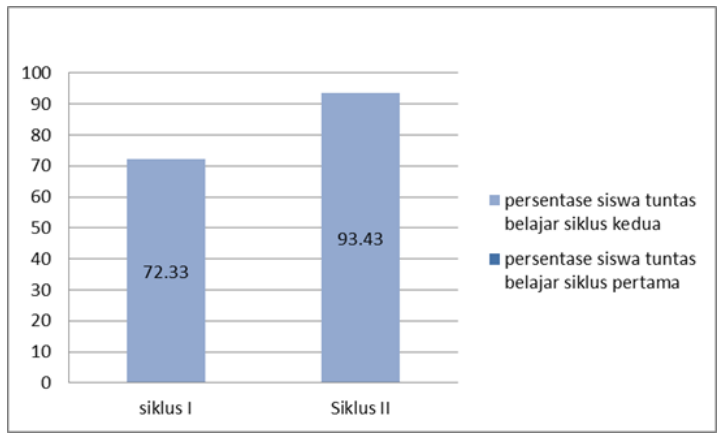

\section{Gambar 3 Grafik Hasil Belajar siswa Pada Siklus I dan Siklus II}

Dari data hasil observasi terhadap aktivitas siswa, dapat disimpulkan bahwa aktivitas siswa selama mengikuti proses pembelajaran siklus kedua dengan menggunakan metode Probing Promptin gmengalami peningkatan. Keaktifan siswa pada siklus pertama yaitu $69,40 \%$ menjadi $81,33 \%$ pada siklus kedua. Peningkatan aktivitas siswa dari siklus pertama ke siklus kedua nilai siswa jika dirata-rata mencapai nilai 81,33 dengan rata-rata komulatif kelas yang mendapat nilai 75, maka dapat disimpulkan kelas aktif.dapat dilihat pada gambar berikut ini :

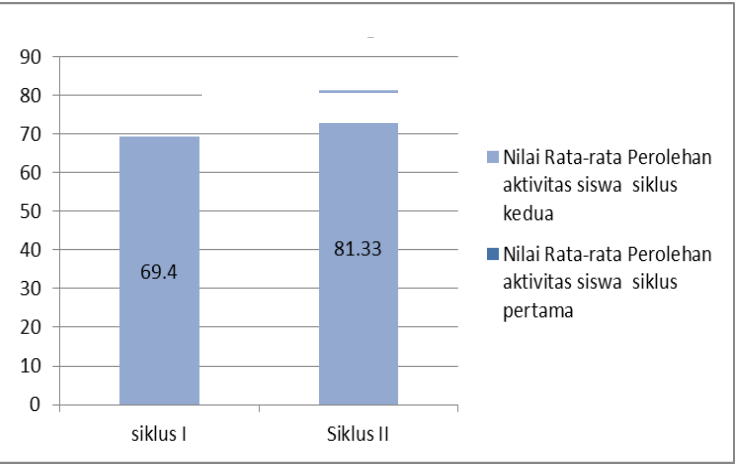

Gambar 4 Grafik Peningkatan Aktivitas Siswa

Adapun keberhasilan yang diperoleh pada siklus kedua ini adalah :

a. Aktivitas siswa dalam proses pembelajaran dengan menerapkan metode Probing Prompting sudah meningkat. Siswa dapat berkomunikasi dan berinteraksi dengan baik, hal ini dapat diketahui dari hasil observasi siklus I dan siklus II selama penelitian penulis didalam kelas.

b. Dengan pembelajaran metode Probing Prompting siswa semakin memahami mata pelajaran konstruksi bangunan. Siswa lebih 


\section{Penerapan Metode Pembelajaran Probing Prompting Untuk Meningkatkan Aktivitas dan Hasil Belajar Siswa Pada Mata Pelajaran Konstruksi Bangunan di Kelas X Program Keahlian Tenik Gambar Bangunan SMK Negeri 1 Stabat}

antusias belajar karena proses pembelajaran di kombinasikan dengan tanya jawab antar siswa.

Hal ini membuktikan bahwa siklus selanjutnya tidak perlu dilakukan lagi. Karena penerapan pembelajaran metode Probing Prompting dapat meningkatkan Aktivitas dan Hasil Belajar Siswa kelas X Program Keahlian Teknik Gambar Bangunan SMK Negeri 1 Stabat Tahun Ajaran 2015/2016.

Dalam penelitian ini, peneliti bekerjasama dengan guru menerapkan metode pembelajaran Probing Prompting. Selama proses pembelajaran berlangsung siswa diajak untuk lebih aktif dalam mengemukakan ide, atau gagasan dari pengetahuan yang diperolehnya. Adapun hasil yang diamati dalam penelitian ini adalah aktivitas dan hasil belajar siswa.

Pada saat melakukan observasi pada siklus I, selama pembelajaran berlangsung siswa masih bingung, dan suasana masih tegang. Hal ini disebabkan karena siswa belum terbiasa dengan menggunakan metode pembelajaran Probing Prompting pada saat proses pembelajaran. Siswa juga masih kurang berani dalam menjawab pertanyaan dan menyampaikan pendapatnya. Berdasarkan hasil observasi pada siklus II, diperoleh peningkatan aktivitas siswa, presentase aktivitas kegiatan siswa pada siklus I adalah sebesar $69,40 \%$ dan pada siklus II naik menjadi sebesar $81,33 \%$. Hal ini disebabkan siswa telah terbiasa dengan menggunakan metode pembelajaran Probing Prompting pada saat proses pembelajaran. Siswa lebih berani menjawab pertanyaan guru dan menyampaikan pendapatnya. Suasana didalam kelas juga tidak terlalu tegang seperti pada siklus I, sikap ramah yang diberikan guru, adanya canda tawa pada saat memberikan pertanyaan membuat suasana didalam kelas tidak tegang.

Berdasarkan hasil penelitian ini, diperoleh rata-rata hasil belajar siswa yang lulus KKM pada siklus I adalah $67,21 \%$ dan rata-rata nilai hasil belajar siswa pada siklus II adalah 93,43 $\%$. Peningkatan hasil belajar siswa merasa tertarik dan termotivasi untuk belajar dengan adanya penggunaan metode pembelajaran Probing Prompting dalam proses pembelajaran. Data pada siklus II sekaligus menunjukkan bahwa secara klasikal kelas tersebut tuntas belajar, sebab ketuntasan klasikal tercapai apabila mencapai KKM $>75$.
Melalui metode pembelajaran Probing Prompting dapat membuat siswa lebih aktif secara tidak langsung dan membantu siswa dalam meningkatkan hasil belajarnya seperti yang tercapai dalam penelitian ini. Dengan demikian, berdasarkan hasil analisis data diatas dapat disimpulkan bahwa penerapan metode pembelajaran Probing Prompting dapat meningkatkan aktivitas dan hasil belajar siswa pada mata pelajaran konstruksi bangunan di SMK Negeri 1 Stabat.

\section{Kesimpulan, Implikasi dan Saran}

\subsection{Kesimpulan}

Dari hasil analisis data dan pembahasan maka diambil kesimpulan, yaitu :

a. Aktivitas belajar siswa selama penerapan metode pembelajaran Probing Prompting pada siklus I kurang mencapai standar minimal yang diharapkan, sehingga perlu dilakukan siklus selanjutnya (siklus II). Berdasarkan hasil observasi Siklus I diperoleh bahwa persentase aktivitas belajar sebesar $69,40 \%$ yaitu tidak aktif (pasif). Dengan demikian ketuntasan belajar pada siklus I belum tercapai sehingga dilanjutkan dengan siklus selanjutnya. Selanjutnya berdasarkan hasil observasi pada siklus II diperoleh persentase aktivitas siswa sebesar 81,90\% dengan kategori baik.

b. Berdasarkan analisis data dan pembahasan hasil penelitian yang diperoleh adalah metode pembelajaran Probing Prompting dapat meningkatkan hasil belajar pada mata pelajaran Konstruksi Bangunan pada siswa kelas $X$ di SMK Negeri 1 Stabat tahun ajaran 2015/2016. Hal ini dapat dilihat dari nilai hasil belajar mata pelajaran Konstruksi Bangunan pada Siklus I nilai hasil belajar dengan kategori tidak tuntas sebanyak 10 siswa $(33,33 \%)$, cukup 11 siswa $(36,66 \%)$, baik sebanyak 9 siswa (30\%) dan tidak ada yang sangat baik. Dari nilai ideal 100, nilai perolehan rata-rata hanya $71,21 \%$ yaitu belum tuntas. Berdasarkan data hasil pada siklus II diperoleh bahwa rata-rata hasil belajar siswa yang tuntas belajar sebanyak 28 siswa atau 93,33\% dan yang tidak tuntas sebanyak 2 siswa atau 6,67\%. Pada siklus II siswa telah mencapai ketuntasan belajar secara klasikal. 


\subsection{Implikasi}

Hasil penelitian menunjukkan bahwa terjadinya peningkatan aktivitas dan hasil belajar belajar siswa pada pembelajaran mata pelajaran Konstruksi Bangunan, dikarenakan :

a. Siswa lebih aktif dalam proses pembelajaran, hal ini diketahui dari indikator pada lembar observasi aktivitas siswa yaitu aktif dalam bertanya, memberikan jawaban, memberikan pendapat, dan membuat kesimpulan dalam proses belajar dan pembelajaran. Peningkatan keaktifan siswa dapat dilihat dari lembar observasi siswa yaitu nilai rata-rata 69,40 pada siklus I meningkat menjadi nilai rata-rata 81,33 pada siklus II. Sehingga diketahui bahwa hipotesis pertama dapat diterima dalam meningkatkan keaktifan atau aktivitas belajar siswa.

b. Pada siklus I diberikan materi pelajaran tentang pemahaman konstruksi bangunan dan pemahaman mengenai jenis konstruksi dengan nilai rata-rata 72,33 meningkat pada siklus II dengan materi bagian atau elemen-elemen konstruksi dan pemahaman mengenai prosedur memilih bahan bangunan dan pendimensian dengan nilai rata-rata 85 . Sehingga diketahui bahwa hipotesis kedua diterima meningkatkan hasil belajar siswa

\subsection{Saran}

Berdasarkan kesimpulan diatas maka disarankan beberapa hal sebagai berikut :

a. Sebaiknya guru memberi motivasi dan dorongan kepada setiap siswa setiap kali sebelum pembelajaran dimulai.

b. Guru harus melatih keterampilan dan mendorong keberanian siswa dalam menjawab dan mengajukan pertanyaan.

c. Penggunaan metode pembelajaran Probing Prompting dapat dijadikan salah satu alternatif yang digunakan sebagai upaya untuk meningkatkan aktivitas dan hasil belajar siswa.

d. Karena kegiatan ini sangat bermanfaat khususnya bagi guru dan siswa, maka diharapkan kegiatan ini dapat dilakukan secara berkesinambungan dalam mata diklat konstruksi bangunan maupun pelajaran lain.

e. Pihak sekolah harus menambah referensi materi yang akan diajarkan sehingga perhatian siswa lebih terfokus pada materi pelajaran dalam meningkatkan hasil belajar.

\section{Daftar Pustaka}

Arikunto, Suharsimi. 2008. Penelitian Tindakan Kelas. Jakarta : Bumi Aksara

Arikunto, Suharsimi. 2006. Dasar-Dasar Evaluasi Pendidikan. Jakarta : Bumi Aksara

Dimyati, Mudjiono.2013, Belajar dan Pembelajaran. Jakarta : Rineka Cipta

Djamarah, S.B dan Zain, A. (2010). Strategi Belajar Mengajar. Jakarta: Rineka Cipta.

Hanafiah, Nanang \& Cucu Suhana. 2010. Konsep Strategi Pembelajaran. Bandung: Refika Aditama.

Huda, Miftahul. 2013. Model-model Pengajaran dan Pembelajaran. Yogyakarta: Pustaka Pelajar.

Kamsinah.2008. Metode dalam peroses pembelajaran: studi tentang ragam implementasinya.Lentera Pendidikan Vol. 11 No.1

Kunandar.2008. Langkah Mudah Penelitian Tindakan Kelas Sebagai Pengembangan ProfesiGuru.Jakarta : Raja Grafindo Persada.

Ngalimun, 2012. Strategi dan Model Pembelajaran. Banjarmasin. Scripta Cendekia

Sagala. Syaiful. 2011. Konsep dan Makna Pembelajaran. Bandung: Alfabeta

Sanjaya, Wina. 2010. Strategi Pembelajaran Berorientasi Standar Proses Pendidikan. Jakarta: Kencana

Sardiman. 2011. Interaksi dan Motivasi Belajar Mengajar. Jakarta: Rajawali.

Sisdiknas. 2003. Undang-undang Republik Indonesia No. 20. Tahun 2003. Bandung: Citra Umbara.

tanggal 24 Agustus 2014

Sutikno, Sobry. 2008. Belajar dan Pembelajaran. Prospect, Bandung.

Slameto. 2010. Belajar dan Faktor-Faktor yang Mempengaruhinya. Jakarta : Rineka Citra 